\title{
AVALANCHE DYNAMICS. REVIEW OF EXPERIMENTS AND THEORETICAL MODELS OF FLOW AND POWDER-SNOW AVALANCHES*
}

\section{By Thomas Scheiwiller and Kolumban Hutter}

(Versuchsanstalt für Wasserbau, Hydrologie und Glaziologie, Eidg. Technische Hochschule Zürich, CH-8092 Zürich, Switzerland)

\begin{abstract}
The paper of which this is an extended abstract reviews theoretical formulations for flow and airborne powder-snow avalanches. First powder-snow avalanches are considered as plane turbulent gravity currents. Then we propose a two-phase model describing powder-snow avalanches as turbulent binary mixtures of snow granules and air. An analogy is postulated between flow avalanches and the rapid shear flow of granular materials which leads to a non-polar continuum with microstructure taking into account the fluctuation energy of the snow granules.
\end{abstract}

RÉsumé. Dynamique des avalanches. Aperçu des expériences et modèles théoriques concernant les avalanches coulantes et poudreuses. Cette publication est un résumé détaillè de l'article publié par Scheiwiller et Hutter (1982). Un aperçu des théories pour décrire des avalanches coulantes et des avalanches poudreuses y est donné. D'abord les avalanches poudreuses sont considérées comme courants de densité turbulents. Ensuite une théorie biphasique est proposée, les avalanches poudreuses étant des mélanges binaires turbulents de neige et d’air. Une analogie est postulee entre les avalanches coulantes et les courants visqueux rapides d'un granulat, ce qui mène à un continuum non polaire avec microstructure, tenant compte de l"énergie de fluctuation des particules de neige.

Zusammenfassung. Lawinendynamik. Überblick über Experimente und theoretische Modelle von Fliessund Staublawinen. Die vorliegende Publikation ist eine erweiterte Zusammenfassung einer Arbeit von Scheiwiller und Hutter (1982), in der eine Übersicht über theoretische Modelle für Fliess- und Staublawinen gegeben wird. Zuerst werden Staublawinen als turbulente Schwerkraftströme betrachtet. Dann wird ein Zweiphasenmodell vorgeschlagen, welches Staublawinen als turbulente Binärmischungen aus Schneepartikeln und Luft beschreibt. Für die Fliesslawinen wird eine Analogie mit der raschen Scherströmung granularer Materialien postuliert, was zu einem nicht-polaren Kontinuum mit Mikrostruktur führt, die der Fluktuationsbewegung der Schneepartikel Rechnung trägt.

THIS abstract summarizes a report on avalanche dynamics which has been written in German by Scheiwiller and Hutter (1982) and which will not be published in another form, but can be obtained on request from the Versuchsanstalt für Wasserbau, Hydrologie und Glaziologie. It deals with theoretical formulations which have been proposed as suitable models for flow avalanches and for air-borne powder-snow avalanches or are thought to be appropriate for the description of these.

Part A deals with powder-snow avalanches. First, Voellmy's model equations (Voellmy, 1953), which were derived by analogy with hydraulic channel theory, are discussed. Then, Tochon-Danguy's and Beghin's models are introduced (Tochon-Danguy, unpublished; Beghin, unpublished). In these formulations avalanches are considered as turbulent gravity currents. Tochon-Danguy distinguishes two different flow regimes, namely the case of a gravity current that is fed continuously from a reservoir (long gravity current), or the movement of a fixed

* This paper summarizes a fuller report (Scheiwiller and Hutter, 1982) which is obtainable from the authors institution on request and of which copies have been deposited for archival purposes with the World Data Centres for Glaciology in Boulder, Colorado, U.S.A., in Moscow, U.S.S.R., and in Cambridge, England. 
amount of turbidized snow down a slope (short gravity current). Either of these two idealized flow regimes represents some features of a real powder-snow avalanche. The short gravity current model could be a suitable formulation for the motion of the head of the avalanche (if snow entrainment from the ground is neglected), while the long gravity current model could describe the movement of the tail of the avalanche body. In the final section of Part A powdersnow avalanches are considered as binary mixtures of air and solid snow granules moving downslope as a two-phase gravity current. This leads to momentum and mass-balance equations for both snow and air separately which include in the model the possibility of the settlement of snow particles. The need for a formulation with two momentum equations is seen very easily, as a classical diffusion model with two continuity but one momentum equation allows a diffusion and thus a decrease of tracer concentration only; the sedimentation process leads to a local increase, however. As in most boundary-layer theories, the local balance equations are integrated vertically over the boundary-layer thickness, which in our case is the avalanche height. In order not to loose all information about the density and velocity profiles by this integration, the method of weighted residuals (Kantorovich and Krylov, 1936) is used. The problem of a plane steady gravity current, or more precisely, steady motion in the long gravity current flow regime leads in this integration scheme to a spatially one-dimensional description by ordinary differential equations which can be solved numerically with whatever ODE-integrator is available. The model equations are such that any topography can be accounted for. One of the most important terms in this two-phase model is a transfer term which couples the momentum balances of air and snow. This term describes interphase friction and seems to be crucial to the powder-snow avalanche process.

Part B deals with flow avalanches. An analogy is postulated between flow avalanches and rapid shear flow of granular materials. Thus the movement of a dense mass of hard snow granules is analysed. The difference between the formulations for powder-snow and flow avalanches consists in neglecting the effect of the surrounding air for the latter. Here the interaction between the granules is now all-important. Hence this model could also be suitable for the description of rock avalanches, ice avalanches, mud flow, flow of sand, etc. The experimental observations that have been made by Bagnold (1954) and others are discussed, in particular Couette and Poiseuille flow and plane shear flow down a chute. Next, continuummechanical formulations are presented which conform with these experimental facts. It is shown that a theory consisting of the mechanical balance equations of mass and momentum alone is in certain cases self-contradictory, no matter how sophisticated the constitutive law for the stress tensor might be. Hence, an equation taking into account microstructural effects is needed. Thus, in order to obtain a consistent theory the "classical" balance equations are complemented by a balance law for the fluctuation energy of the snow granules. Its origin lies in the interparticle collisions. The balance equations for the mean fields are derived in the same way as those in a turbulent medium by splitting up the field values into a mean and a fluctuating part and then averaging the equations. The balance equation for the fluctuation energy emerges as the contracted averaged velocity moment of the momentum equation. The closure of the set of differential equations requires not only constitutive laws for a stress tensor, but also for the flux and the dissipation of fluctuation energy. There are suggestions for these constitutive laws based on analogies with turbulence theory. A clear and systematic derivation, however, requires the use of methods of statistical physics. The model presented is based upon the statistics of identical, hard, spinless spheres, and the derivation of the constitutive relations is similar to that in the kinetic theory of gases. It leads to a classical non-polar continuum with microstructure, the only 
free parameters being the particle diameter, the coefficient of restitution (describing the "amount of inelasticity of the particle collisions", and a third parameter which is a measure for the anisotropy of the statistical two-particle distribution function (Jenkins and Savage, in press).

There exist formulations for the movement of granular materials which take into account the microstructural effects by a balance law for the volume fraction occupied by the granules rather than one for the fluctuation energy (Goodman and Cowin, 1972). These theories have less physical evidence and, judging by the results, seem to be less useful than models which apply the balance equation for the fluctuation energy.

In the final section it is demonstrated how complex a mathematical model must be which incorporates the spin exchange of the particles during collisions (Kanatani, 1979). The structure of these models is that of polar continua. It might be necessary for wet flow avalanches to be described by such a polar model.

MS. received 6 September 1982

\section{REFERENCES}

Bagnold, R. A. 1954. Experiments on a gravity-free dispersion of long spheres in Newtonian fluid under shear. Proceedings of the Royal Society of London, Ser. A, Vol. 225, No. 1160, p. 49-63.

Beghin, P. Unpublished. Étude des bouffées bidimensionnelles de densité en écoulement sur pente avec application aux avalanches de neige poudreuse. [D.-Ing. thesis, Université Scientifique et Médicale de Grenoble, 1979.|

Goodman, M. A., and Cowin, S. C. 1972. A continuum theory for granular materials. Archives for Rational Mechanics and Analysis, Vol. 44, No. 4, p. 249-66.

Jenkins, J. T., and Savage, S. B. In press. A theory for the rapid shear flow of identical, smooth, nearly elastic spherical particles. Journal of Fluid Mechanics.

Kanatani, K. I. 1979. A micropolar continuum theory for the flow of granular materials. International Journal of Engineering Science, Vol. 17, No. 4, p. 419-32.

Kantorovich, L. V., and Krylov, V. I. 1936. Metody priblizhennogo resheniya uravneniy v chastnykh proizvodnukh. Leningrad, Glav. Red. Obshchetekhn. Lit.-rm. |English translation: Approximate methods of higher analysis. Translated by C. D. Benster. New York, Insterscience Publishers, 1958.|

Scheiwiller, T., and Hutter, K. 1982. Lawinendynamik. Übersicht über Experimente und theoretische Modelle von Fliess- und Staublawinen. Mitteilungen der Versuchsanstalt für Wasserbau, Hydrologie und Glaziologie an der Eidgenössischen Technischen Hochschule (Zürich), Nr. 56.

Tochon-Danguy, J. C. Unpublished. Étude des courants de gravite sur forte pente avec application aux avalanches poudreuses. [D.-Ing. thesis, Université Scientifique et Médicale de Grenoble, 1977.|

Voellmy, A. 1955. Über die Zerstörungskraft von Lawinen. Schweizerische Bauzeitung, Jahrg. 73, Ht. 12, p. I59 62: Ht. 15, p. 212-17; Ht. 17, p. 246-49; Ht. 19, p. 280-85. 